\title{
Joseph P. Day
}

On April 10, 1944, occurred the death of Joseph P. Day of New York, a member of the Business Historical Society. With his passing went one of the most colorful, dynamic, and influential figures in New York real estate of the three decades before 1929.

Joseph P. Day was born in the city of New York on September 22,1873 . Orphaned as a young boy, he received only a public school education and went to work early. His first job was in the establishment of James Talcott, drygoods commission merchant and factor in New York. He began to work as an office boy, at the rate of $\$ 1.92$ a week, and one of his tasks was to sweep out the office before the clerks came at 8 o'clock; after a few years his employer let him try selling, which he did so effectively that, though still a boy, Joe Day became a junior salesman at $\$ 10$ a week. It is said that he considered himself a protégé of James Talcott and habitually went to him for advice in later years.

At the age of twenty-one Day entered the insurance and realestate business, and he was well established in real estate by the time the great real-estate boom began in New York about 1900. As a real-estate broker, appraiser, and auctioneer, he rose to leadership in New York City in its period of greatest expansion. His first big year was 1907, and from then on until 1928 his sales were very large. Seeing the possibility of developing outlying areas as the subway reached outward and better transportation was provided for commuters, he became the prime factor in getting many great estates divided up and sold for building lots, among them such old ones as the Ogden, Astor, Gould, and Van Cortlandt estates. In the late 1930's he sold at auction real-estate holdings of closed national banks. His last large transaction was the purchase in 1942 of the Manhattan Beach property for the United States for war purposes.

Joseph P. Day's success in real estate won for him positions of responsibility in a number of associations and corporations. He served as president of the Real Estate Auctioneers' Association and of the Real Estate Board of New York City. He was also a director of R. H. Macy \& Co., the Consolidated Edison Co., the Metropolitan Life Insurance Co., the Union Carbide Co., and other companies, "all of which," according to the New York Times, "gained the benefit of his knowledge of real estate and of human nature."

142 